\title{
Effect of brand trust and customer satisfaction on brand loyalty in Bahawalpur
}

\author{
Zohaib Ahmed \\ Department of Management Sciences, The Islamia University of Bahawalpur (Pakistan) \\ Muhammad Rizwan (Corresponding author) \\ Lecturer, Department of Management Sciences, \\ The Islamia University of Bahawalpur, Pakistan \\ E-mail: rizwan.arshad@iub.edu.pk
}

Mukhtar Ahmad

Department of Management Sciences, The Islamia University of Bahawalpur (Pakistan)

Misbahul Haq

Department of Management Sciences, The Islamia University of Bahawalpur (Pakistan)

Doi:10.5296/ jsr.v5i1.6568 URL: http://dx.doi.org/10.5296/ jsr.v5i1.6568

\begin{abstract}
Brand Loyalty is the only tool for any company to survive in a severe competition. Brand helps in creating relationship between consumer and producer. In this research we study and investigated the effect of service quality, perceived quality, perceived value, brand trust and customer satisfaction on brand loyalty. The service quality, perceived quality and value were determined to be input variables; brand trust and customer satisfaction were determined to be intervening variables; and brand loyalty was determined to be the output variable. Conceptual model was designed to explain the factors on brand loyalty. Our study based on a self-administered survey that was conducted in Bahawalpur setting. Data were collected from the randomly selected 150 Hewlett Packard product consumers. Our study results provide a better understanding about brand loyalty among customers for companies to analyse and part played by each element in the progress of brand loyalty. Moreover it highlights the crucial role played by affective elements.
\end{abstract}

Keywords: Brand loyalty, brand trust, customer satisfaction 


\section{Introduction}

Brand is an important subject which creates positive image in eyes of customers to make itself different from the competitors(kotler,2004). Today in the age of globalization internet is now spreading in the world quickly as compared in the past due to this the competition among the products are more severe to survive. This makes brand more important and uplift at high level. In the world of marketing and other businesses brand is growing up as an issue and become more important at international level. In the intensive competition to make the customers loyal to brand marketing strategies help to create positive image. An organization can determine its success by the degree of their brand rather than to build a new plant or technical innovation. Loyal customers even at toughest times purchase the product offering at high rate.

In the process of product choice by the customers brand plays an important role. The mean of this process is to create a link between the producer and consumer to provide them the functions that are promised by the product to meet his or her expectations. That's why customers consider brand in the product selection process when they intend to purchase. If customers aware more about the role and importance of brand they would be more loyal to the brand product. This creates a strong link between brand and loyalty about that brand. Brand loyalty concept is complicated and not one dimensional (Ha, 2005). The existence of the loyalty to brand is possible when customers feels that the product has right characteristics according to the quality and price of the product.

Brands are the asset of organizations. They interlink consumer and the company that build customers trust and loyalty to the brand. So that this loyalty brings greater market share when the product is purchase by the customers loyal to the brand (Assael 1998). Brands are considered as the more important assets of the company that make customers loyal and have value for the end consumer. Thus the brand helps customers in purchase decision making. Furthermore brand creates a relationship with the customers either the relation is positive by continuing the brand or negative by moving to the other brand.

The committed consumers purchase the brand repeatedly. The preference of a person is affected by the behaviour of consumer that resulted in brand loyalty. There is a consistency in buying a product from the preferred brand class at any price. Different marketing steps are taken by the companies to make the customers loyal. They used different programmes to attract the customers. In return they get the customers loyal to them and talked about the brand among friends positively. This positive word of mouth is very effective for the company that helps them in gaining the great market share.

The understanding about the needs and wants of the customers is important but majority of the companies failed to do it. The power of the customers of understanding about the products in present day is more as compared in the past. In this result customers remain unsatisfied. Thus not only credibility but loyalty of the brand is also affected directly and indirectly by this dissatisfaction of customers. In the beginning point, customer's satisfaction is built if the customer has full confidence or trust on the brand. If brand fails to fulfil promises customer will move to the competitor brand product. 


\section{Macrothink}

The research scholars have now complete understanding about brand loyalty that is of great advantage for the companies from past few years. There are many studies about focus on advantages of customer loyalty to the brand andtheir strength to attain great outcomes (Oliver, 1999; Russell-Bennett et al., 2007).From the practical point of view, in order to enhance the brand experience it's important to know how loyalty to the specific brand can be reinforced.in this observation loyalty of customer shows a wider role and connect the company, its employees and shareholders with the final consumer of the product. Similarly brand is a main mean to understand the consumer brand link.

Every of the firm want to attract the customers and they would have the high brand feeling about the product. For this purpose customer satisfaction is necessary factor that can move the customers towards it. From this point of view if the customers will satisfy with their specific brand they would make repeat purchases and show commitment. Not only satisfaction various other factors affect the brand loyalty of consumer include trust, quality perceived value, equity. These factors are helpful in creating the multidimensional construct of brand loyalty. In this research we are studying the variables including service quality, perceived quality, perceived value, customer satisfaction, brand trust and their effect of brand loyalty. These determinants are designed to know the effects on brand loyalty.

The loyal customers of specific brand probably willing to pay any price for the product (Jacoby and Chestnut 1998; Pessemier1959 ; Reicheld 1996). All this is due to the communication of the brand, trust of the customer and better service quality offered by the brand make consumer attractive to use it. Companies achieve the great share in market if loyal consumers purchase the brand constantly (Assael 1998). Moreover loyal consumers have a perfect image in their sights to use the product repeatedly overtime (Upshaw 1995).Higher brand performance results and customer brand association may builds brand trust and loyalty that was a result of better communication and great service quality. Thus the loyalty to this brand can be understand through trustworthiness, service quality and perceived quality.

\section{Literature review}

\subsection{Brand loyalty}

A situation in which consumer purchase and uses the brands of their trust as compare to brand that they don't trust. In this way consumer shows a commitment to that brand. Brand loyalty can be measured through positive word of mouth, satisfaction of customer, brand trust, sensitivity of price etc. A degree in which consumer consistently purchases the brand available in the product category. The loyalty to the specific brand of consumer will remain unchanged if the brand is as long available (Rizwan et al., 2013). Today's customer has more power of understanding about the brand and they will buy the brand from specific product category if they feel that the product has right characteristics, quality and price. Moreover they don't move towards other suppliers to purchase the product. Also if the other brands are available at low prices having higher quality, consumers will remain loyal to their specific 
brand.

If the company wants to achieve the profitability and compete with their rival products brand loyalty is condition for it (Aaker, 1995, 1997; Reichheld, Markey, and Hopton, 2000).Companies offer many brands to their customers but unfortunately not every brand attracts the customers. Only few brands give company higher loyalty customers. Marketing strategies are the heart of company to build a customer brand relationship; particularly in intensive competition by reducing the product disparity (Fournier and Yao, 1997).From the literature point of view brand loyalty in marketing has now great importance from last few decades (Howard and Sheth 1969).

Due to the better perceived quality or positive image of brand the loyal consumers prefer to purchase the specific brand but not for the price (Chaudri, 1999). Through the attributes and good quality habit brand can be identified (Jacoby and Kyner, 1973).In general the customer level of satisfaction can be identified either the brand fulfil their expectations or not through the means of brand loyalty (Bloemer and Kasper, 1995; Ballester and Aleman, 2001). The performance of the brand is recognized by higher customer's loyalty.

\subsection{Brand trust}

It is a promise of brand with their customers to fulfil their expectations. Brand trust is an important item that helps customer loyal to the brand. Without the trust on brand customer can't enter in loyalty set. To build a trust it's important for the Consumer to take and asses the information from the product. Companies can build emotional trust if they can prove that the brand is only for the customers and meet their expectations (e.g. brand is trustworthiness and friendly for the family use).Consistent brand demonstrate this specific behaviour.

The customers trust on specified brand functions and willingness to purchase the brand from the product class (Moormal et al 1993). The vagueness in the situation can be diminishes by the trust through which customer can rely on the specific trusted brand product. Brand loyalty is a result of brand trust or promises that build the highly valued connections Morgan and Hunt 1994, Chaudhuri and Holbrook, 2001).Some scholars defined commitment as "an enduring desire to maintain a valued relationship" (Moorman, Zaltman, and Deshpande 1992).So promises are the cause of constant on going and retaining a relationship build between company and consumer.

\section{H1: Brand trust positively correlated with brand loyalty}

\subsection{Service quality}

Service quality can be defined as the observation of customer about service items that include quality of physical atmosphere, resulted quality, and interfaced quality. Furthermore these service items can also be estimated on the basis of detailed dimensions of quality, awareness, consistency and promises. In addition to this, service quality contains the exchange of 
relationships between salesperson and the purchasers. Due to the better services provided customer wants to avail the services at shop. This resulted in the extensive coordination between salesperson and consumer.

Service quality can be defined as the divergence between customer image about the service presentation and his/her expectations for services. Service quality is an essential item in building the brand trust and defined in other words as the decisions that are resultant from estimation process in which customers differentiate the service provided to them and the services they perceived (Parasuraman et al, 1988) Gronroos (1984).

The customer's decision about the whole performance of the service product ( Zeithaml 1988). If the quality experienced by the customer is according to the quality they expect about the brand this resulted in a better service and perceived quality Gronroos (1988). The model of service quality that got fame was presented by Parasuraman et al. (1985, 1988). There is a major effect of service quality on the loyalty of customer (Bolton and Drew 1991). Some scholars suggested that only those elements have major effect on brand loyalty that is not intangible but gives response (Kayaman and Arasli 2007). The quality perceived by the customer and their satisfaction level the indirect link among brand loyalty and service quality can be defined (Chitty et al., 2007).

In service organizations they must have to facilitate the customer with their consistent and best service qualities that can make them at the top in the competition of services provided. The point to keep in mind while in competition is to provide customers with their consistent and best products, loyalty of customers with brand and mitigating cost (Rusta, 2008).

Practical research also clearly defined the relationship between the service quality, brand trust and loyalty of customers towards the brand. The behaviour of the customer and intention towards the services and its multidimensional structure was proposed by the scholar (Zeithaml et at. 1996). Positive word of mouth, intention of customers towards the brand, sensitivity in price and behaviours of complaining about it are the main four measurements that completely described the multidimensional framework.

\section{H2: Service quality is positively correlated with brand trust}

\subsection{Customer satisfaction}

It can be defined as the degree to which customers are happy with the use of products that are provided to them by the companies. To achieve the level of satisfaction companies must have to keep in mind the needs and wants of customers and supply them outstanding products and services. Any business can move on to the upper level of advantage by achieving customer satisfaction in intensive competitive market. It is a feeling of any consumer post purchases and uses of the product, regardless that product and services meet the expectations or not.

Originally customers make their expectation and perception about the brand product by means of positive word of mouth from the friends and family, the selling and promotion activities by using the market strategies. If the customers found unsatisfied from the product 
and services it is possibility that they can tell others about such practice.

It is commonly used in studies. Basically satisfaction is a speedy or quick experience of the customers after using the product through which the overall satisfaction can be assessed (Lam, et al, 2004; Tian, 1998; Yang, 2004; Li and Vogelsong, 2003). Various studies tells that the loyalty is affected by the satisfaction through the satisfaction level we can predict the purchase intentions and behaviour of consumer towards the brand product (Eggert, A. \&Ulaga, 2002). In making a decision to purchase the product past experiences of using that product affects the intention of consumer decision process.

From the past few decades many marketers and research scholars define customer satisfaction. In the words of (Oliver 1997) satisfaction is defined as "the summary psychological state resulting when the emotion surrounding disconfirmed expectation is coupled with prior feelings about the customer experience".

Practical studies illustrate that satisfaction is the predecessor of brand loyalty, intention to rebuy the product and behavior of brand towards its customers (Oliver, 1980; Pritchard et al., 1999; Russell- Bennett et al., 2007). Brand loyalty can increased by the satisfaction of customer and repeat the purchase of the same product services (LaBarbera and Mazursky, 1983). In the research repurchase and consumption of the product leads to the two phases of loyalty that are as, loyalty to purchase and loyalty towards attitude or behavior through which it can be determined either consumers will purchase those services or move to other that are more preferable (Bennett, Härtel, and McColl- Kennedy, 2005; Chaudhuri and Holbrook, 2001).Thus, the following hypothesis is arrived:

\section{H3: Customer Satisfaction will be positively correlated with brand loyalty}

\subsection{Perceived brand quality}

The customer's perception about the product and services quality. It is the perception of the customer created by the companies through the advertising publicities, and other social media intend to purchase the product. In general it is the feeling of customer about product quality and its features provided to them such a performance and reliability of the product. The promises made by the brand product to meet the expectations of the customers (Zenithal, 1988). Basically there are two phases of the quality objective and perceived quality. According to, Zeithaml (1988) objective quality has no validity and valuations of the quality. Furthermore from this point of view perceived quality is significant among them which are also a second phase or part of the quality. The customer valuations for the product quality and services either product meets the expectations (Olsen, 2002). It is a relative concept that can change the people's experiences and expectations of that product brand. Some researchers and practitioners had considered the relation of perceived quality and satisfaction by Olsen (2002), Darsono and Junaedi (2006). There are many models presented by the, Cronin and Taylor (1992) to examine the link of perceived quality and satisfaction. Through Some practical researches it is also found that there is a supportive link between perceived quality and satisfaction Lee and Back (2008). In some other quality studies this link has been 
described (Brady and Robertson, 2001; Fornell, 1992; Tse and Wilton, 1988) According to Gotlieb et al.'s (1994) there is a consistent relation between perceived quality and customer satisfaction. If the link of perceived quality and satisfaction become consistent then it is best for the brand loyalty. Thus perceived quality has positive effect on brand satisfaction. Perceived quality has also an effect on the brand trust which suggested by many researchers Corritore et al., (2003). Through this result it is generally came to knew that there is a positive effect of perceived quality on brand trust. The following hypothesis are developed from the literature

$\mathrm{H} 4$ : perceived quality is positively correlated with customer satisfaction

H5: perceived quality is positively correlated with brand trust

\subsection{Perceived brand value}

Perceived brand value is defined as the value of product according to its price in the mind of customers. Customer doesn't know the cost incurred on the products. Customer just internally after using the product can analyse through feelings that either the price of the product is more than it's worth or not. This is the point that makes customer willing to pay for the product or not. So in such situation manufacturers or producers apply marketing strategies to create high value of the product and services in the eyes of customer.

It also tells the post purchase intentions and feelings of the customers about the product worth. Furthermore customers then create an image of product in mind positive or may be negative. (Hellier et al., 2003) suggested that it's an observation of customers that the advantages are provided to them are according to price or they satisfy from that product or not. When customer purchases a product he/she wants to get more value than its cost this is the level of satisfaction and expectations of customers for product.

There is association between perceived value and satisfaction suggested by Cronin et al. (2000). Moreover the outcomes told that a significant relationship is between perceived value and satisfaction. The value of product in eyes of customer would be high if customer gets more satisfaction from the specific brand product.

Some scholars studied that there is significant relationship between perceived value and brand trust Chaudhuri and Holbrook (2001). Product value in eyes of customer would increase if the trust of customer on brand is high. Thus the hypotheses we get from a literature are as follows:

H6: Perceived value is positively correlated with customer satisfaction.

\section{H7: Perceived value is positively correlated with brand trust}

\section{Research Methodology}

The nature of current study is descriptive that explains the whole phenomenon. Descriptive 
research can be explained as to describing something, some phenomenon or any specific situation. In Descriptive research we explain the phenomena or situation not any type of interpretation occurs in the descriptive research (Creswell.1994). The first purpose of the descriptive research is verification of the developed hypotheses that reflect the current situation. This practical and descriptive study shows the reliability of the questionnaire.

\section{Sample/Data}

A sample of 150 Hewlett Packard product users were randomly selected, for this purpose the study based and developed through conducting self-administered questionnaires. The data was collected from Bahawalpur City and consumers were asked to participate in this research to collect the information about brand loyalty. The current study utilizes a technique that is convenience sampling. It is a sampling technique in which data or relevant information is collected from the sample/units of the study that are conveniently available (Zikmund, 1997).

\section{Questionnaire and Scales}

There are two major purposes of the survey instrument: first to investigate the relationship of different variables in foundation of brand loyalty and secondary, to gather the information about the respondents of different characteristics that can be used to understand the variations in different classes.

The survey of the study contains two sections. Section 1 contains individual specific and demographic variables. This section tells the respondents gender, age, income, education and status.

While Section 2 include the variables that are under study. These variables include perceived value, brand loyalty, brand trust, customer satisfaction, perceived quality and service quality. The base of this section is on the past literature and already builds and used questionnaires (Table 1)

The scales under this study were taken from previous literature and published studies. First variables contain 4 items and these scales were taken from ((Mathwick et al. 2001; Petrick 2002; Sweeney and Soutar 2001)) ; Second variable contains 6 items these measures were taken from (Algesheimer, Uptal and Herrmann, 2005; Fullerton, 2005; Third variable contains 5 items and these scales were taken fromMatzler it al, (2008). Chanduhuri and Holbrook, (2001) ; Fourth variable contains 4 items and these scales are adopted from Yoo et al (2000) ; Fifth variable has only just 2 items which were taken fromRagunathan and Irwin (2001) ; Sixth or last variable contains 5 items and these were adopted from (Brady and Cronin, 2001; Parasuraman et al, 1988; Terblanche and Boshoff, 2001). 
Table 1: Scales of the study

\begin{tabular}{|c|c|c|c|}
\hline No & Variables & Items & Reference \\
\hline 1 & Perceived value & $\begin{array}{l}\text { 1. The product itself is worthy. } \\
\text { 2. This brand is reasonably priced. } \\
\text { 3. This brand offers value for the money. } \\
\text { 4. This brand is a good product for the } \\
\text { price }\end{array}$ & $\begin{array}{l}\text { ((Mathwick et al. } \\
\text { 2001; Petrick 2002; } \\
\text { Sweeney and Soutar } \\
\text { 2001)) }\end{array}$ \\
\hline 2 & Brand loyalty & $\begin{array}{l}\text { 1. This brand would be my first choice. } \\
\text { 2. I consider myself to be loyal to this } \\
\text { brand } \\
\text { 3. I will not buy other brands if the same } \\
\text { product is available at the store. } \\
\text { 4. I recommend this brand to someone } \\
\text { who seeks my advice } \\
5 \text {. I get good value for my money. } \\
6 \text {. I say positive things about this brand } \\
\text { to other people. }\end{array}$ & $\begin{array}{l}\text { Algesheimer, Uptal } \\
\text { and Herrmann, 2005; } \\
\text { Fullerton, 2005; }\end{array}$ \\
\hline 3 & Brand trust & $\begin{array}{l}\text { 1. I trust on this brand. } \\
\text { 2.I rely on this brand } \\
\text { 3. This is an honest brand } \\
\text { 4. This brand meets my expectations } \\
\text { 5. This brand is safe. }\end{array}$ & $\begin{array}{l}\text { Matzler it al, (2008). } \\
\text { Chanduhuri and } \\
\text { Holbrook,(2001) }\end{array}$ \\
\hline 4 & Perceived quality & $\begin{array}{l}\text { 1. This brand is of high quality. } \\
\text { 2.It is likely that the brand is very high } \\
\text { quality } \\
\text { 3. It is likely that brand is of very }\end{array}$ & Yoo et al (2000) \\
\hline
\end{tabular}




\begin{tabular}{|c|c|c|c|}
\hline & & $\begin{array}{l}\text { consistent quality. } \\
\text { 4. It is likely that the brand offer } \\
\text { excellent features. }\end{array}$ & \\
\hline 5 & $\begin{array}{l}\text { Customer } \\
\text { satisfaction }\end{array}$ & $\begin{array}{l}\text { 1.Overall I am satisfied with specific } \\
\text { experience with the brand } \\
\text { 2.I am satisfied with my decision to } \\
\text { purchase from this brand }\end{array}$ & $\begin{array}{l}\text { Ragunathan and } \\
\text { Irwin(2001) }\end{array}$ \\
\hline 6 & Service quality & $\begin{array}{l}\text { 1.This brand provides superior service } \\
\text { 2.This brand offers excellent service } \\
\text { 3.I have always excellent experience } \\
\text { when I use this brand } \\
\text { 4.I feel good about what this brand offers } \\
\text { to its customers } \\
\text { 5.This brand has fair system for the } \\
\text { handling of complaints }\end{array}$ & $\begin{array}{l}\text { (Brady and Cronin, } \\
\text { 2001; Parasuraman et } \\
\text { al, 1988; Terblanche } \\
\text { and Boshoff, 2001) }\end{array}$ \\
\hline
\end{tabular}

\section{Procedure}

The questionnaire was distributed among 170 respondents for collection of data in Bahawalpur. From the above mentioned criteria the respondents were selected for this purpose. From the starting point or before giving the questionnaire the purpose of the research and study was described to them so that they can easily fill up the questionnaire with appropriate response answers. After the collection of data 150 questionnaires were selected and rest of the questionnaires were not including in the research due to invalid and incomplete questionnaires. The setting of the variables were according to the five point Likert scale ( $1=$ strongly agree, $2=$ agree; $3=$ neutral, $4=$ disagree; $5=$ strongly disagree). Data was coded in SPSS programme. To view the results regression analysis was used.

\section{Reliability Analysis}

In this study of brand loyalty questionnaire we use 26 items in measurement of 6 variables and we came to know that the items in this study are more reliable than standard and suggested value 0.50 by Nunnally (1970) and 0.60 by Moss et al. (1998).So these 26 items shows that all these are reliable and valid to measure the opinions of consumers towards brand loyalty. Reliability of items are shown in (Table 2) 
Table 2: Reliability of Measurements Instrument

\begin{tabular}{|l|c|c|}
\hline Scales & Items & Cronbach Alpha \\
\hline Perceived Value & 4 & 0.525 \\
Brand Loyalty & 6 & 0.721 \\
Brand Trust & 5 & 0.633 \\
Customer Satisfaction & 2 & 0.595 \\
Perceived Quality & 4 & 0.629 \\
Service Quality & 5 & 0.617 \\
\hline
\end{tabular}

\section{Hypothesis Testing}

\section{Description of the Respondents}

The respondents personal and demographic collected information such as gender, age, income, education and status are given in the following constructed table (Table 3)

Table 3: Description of the Respondents

\begin{tabular}{|l|l|l|l|}
\hline & Category & Frequency & Percentage \\
\hline Variable & Male & & \\
\hline Gender & Female & 135 & 90 \\
Age & 15 & 10 \\
\hline Income & $\begin{array}{l}15-20 \text { years } \\
20-25 \text { years }\end{array}$ & 107 & 27.3 \\
$25-30$ years & 2 & 71.3 \\
Below 15000 & 103 & 1.3 \\
$15000-25000$ & 34 & 68.7 \\
$25000-35000$ & 10 & 2 & 6.7 \\
$35000-45000$ & 1.3 \\
\hline
\end{tabular}




\begin{tabular}{|l|c|l|l|}
\hline \multirow{3}{*}{ Education } & Above 50000 & 1 & 0.7 \\
& Matriculation & 3 & 2 \\
& Inter & 8 & 5.3 \\
& Bachelor & 114 & 76 \\
Master & 16 & 10.7 \\
& Ms/MPhil & 9 & 6 \\
\hline \multirow{2}{*}{ Status } & Student & 149 & \\
& Employed & 1 & 99.3 \\
& & & 0.7 \\
\hline
\end{tabular}

\section{Hypothesis Testing}

\section{Service quality, perceived quality, perceived value and brand trust}

In order to understand the model of brand loyalty regression results show that there is significant positive relationship between service quality and brand trust with $(\beta=.304)$ and $(\mathrm{p}<0.01)$. This means that service quality helps more than $30 \%$ to create brand trust among customers. Our study validates the hypothesis $\mathrm{H} 2$.

The regression analysis of the study shows that there is a positive significant relationship between perceived quality and brand trust with $(\beta=.362)$ and $(p<0.01)$. Through this result we came to know that perceived quality contribute more than $36 \%$ to create brand trust. From this result we can say that our study supported the hypothesis H5.

Furthermore the relationship between perceived value and brand trust is significant and positive with $(\beta=.146)$ and $(\mathrm{p}<0.05)$. According to this regression analysis result we came to know that perceived value contribute more than $14 \%$ in creating brand trust among customers. So this result gives validation in favour of hypothesis $\mathrm{H} 7$.

\section{Perceived quality, perceived value and customer satisfaction}

Regression analysis of our research shows that there is a positive and significant relationship between perceived quality and customer satisfaction with $(\beta=.389)$ and $(p<0.01)$. This outcome tells that perceived quality contribute more than $38 \%$ in customer satisfaction. Hypothesis $\mathrm{H} 4$ authenticates through this regression outcome. So a relationship between 
perceived quality and customer satisfaction is found.

Based on the regression results we examine that there is insignificant relationship between perceived value and customer satisfaction with $(\beta=.073)$ and $(p>0.05)$. Younger respondents were focused mainly in this research and they were observed to the high perceived value with relative product if mainly sample consist of adults then results could be different about the relation of perceived value and customer satisfaction. So, we conclude that there is no significant relationship between perceived value and customer satisfaction. From this outcome hypothesis H6 is rejected.

\section{Brand trust, Customer satisfaction and brand loyalty}

According to the research study the variables investigated and have a significant positive relationship between brand trust and brand loyalty. Moreover brand trust has a positive effect on brand loyalty with $(\beta=.510)$ and $(\mathrm{p}<0.01)$. This represents that brand trust contribute $51 \%$ to brand loyalty. So, this regression analysis shows that brand trust has positive impact on brand loyalty and which authenticate the hypothesis $\mathrm{H} 1$.

Regression outcome tells that there is positive significant relationship between customer satisfaction and brand loyalty with $(\beta=.132)$ and $(p<0.05)$. This means that customer satisfaction helps more than $13 \%$ in building brand loyalty. On the basis of this result we can say that there is a relationship between customer satisfaction and brand loyalty which is significant and positive from the regression analysis. This research verify hypothesis H3.

Table 4: Regression Analysis results

\begin{tabular}{|l|l|l|l|l|l|l|}
\hline Hypothesis & Model variables & \multicolumn{1}{|c|}{ S.E } & $\beta$ & C.R & $\begin{array}{l}\text { significance } \\
\text { P }\end{array}$ & Results \\
\hline H1 & brand-loy brand-t & .087 & .510 & 6.495 & $* * *$ & Supported \\
\hline H2 & $\begin{array}{l}\text { brand-t } \\
\text { ser-qua }\end{array}$ & .080 & .304 & 3.978 & $* * *$ & Supported \\
\hline H3 & brand-loycus-sat & .076 & .132 & 1.682 & .015 & Supported \\
\hline H4 & cus-sat per-qua & .086 & .389 & 4.697 & $* * *$ & Supported \\
\hline H5 & brand-tper-qua & .073 & .362 & 4.771 & $* * *$ & Supported \\
\hline
\end{tabular}




\section{Macrothink}

\begin{tabular}{|l|l|l|l|l|l|l|}
\hline H6 & $\begin{array}{l}\text { Cus-sat } \\
\text { per-val }\end{array}$ & .099 & .073 & .932 & .353 & $\begin{array}{l}\text { Not } \\
\text { Supported }\end{array}$ \\
\hline H7 & $\begin{array}{l}\text { brand-t } \\
\text { per-val }\end{array}$ & .073 & .146 & 2.186 & .030 & Supported \\
\hline
\end{tabular}

\section{Discussion}

The purpose of this study is to examine the factors affecting brand loyalty. According to the results of study we came to know the loyalty for brand among customers in Bahawalpur for Hewlett Packard products. The multidimensional construct of brand loyalty basically contains five factors; perceived quality, value, service quality, band trust and customer satisfaction.

Previous researches found the significant effect of brand trust on loyalty of customers. From the study, outcome tells that brand trust is the most important factor on brand loyalty having the regression weight $0.510(\mathrm{p}<0.01)$. A highly significant positive relationship is found between brand trust and brand loyalty. This result illustrates that promises of the product with the customers are fulfilled in return a trust on brand creates which is beneficial for the company in making loyal customers. Brand loyalty is a result of brand trust or promises that build the highly valued connections with consumers Morgan and Hunt 1994, Chaudhuri and Holbrook, 2001).Customer satisfaction is found to be another very important aspect that also has significant effect on brand loyalty with regression weight to be 0.132 (p, 0.015). To make customers loyal Companies keep the needs and wants of the customers in mind to satisfy and facilitate them by their best products and services. The study affirmatively proved by this consequence that Brand loyalty can increased by the satisfaction of customer and repeat the purchase of the same product services (LaBarbera and Mazursky, 1983). From the investigation of study Purchase intentions and decision making of the customers are affected by their satisfaction level.

Service quality, perceived quality and value have a significant positive effect on intervening variables. These inputs can bring changes in customers positively to make them loyal or negatively by losing them. From the study of (Olsen, 2002) the customer valuations for the product quality and services either product meets the expectations. In predicting brand loyalty the link of customer satisfaction and perceived quality is found significant from the regression result of analysis to be $(\beta=.389)$ and $(p<0.01)$. From the results we can say that perceived quality has a positive effect in loyalty of customers. Quality wise perception created in minds that help them in creating satisfaction level to increase which then lead the consumers to brand loyalty.

Prior studies examine the relationship between brand trust and perceived quality. This result was also found to be consistent by Corritore et al., (2003). Regression analysis with $(\beta=.362)$ 
and $(\mathrm{p}<0.01)$ as perceive quality is the antecedent of brand loyalty it supports our study that it effects the customers loyalty and trust. Our research tells and supports in form of positive significant relationship with brand trust that leads customer to loyalty of that brand. From the past proved studies researchers and practitioners found that there is a major effect of service quality on the loyalty of customer (Bolton and Drew 1991). Thefinding of this study also affirms by Parasuraman et al (1988) that service quality has positive effect on brand trust. Our study mentions a strong role of service quality in creating a profile of loyal customers with the regression weight being $(\beta=.304)$ and $(p<0.01)$. Quality of the service give benefits not only to customers but more to the company in make themselves a market king so better service quality provides company with great market share. Our study gives a favour in this relationship of service quality and brand trust.

Perceived value is found to be another important factor that affects the brand trust in building brand loyalty. Basically it is the Customer evaluation of product according to the price. Some scholars studied that there is positive significant relationship between perceived value and brand trust Chaudhuri and Holbrook (2001). Our result is found to be consistent with it and gives the regression weight of $(\beta=.146)$ and $(p<0.05)$. Our study conclusions support that perceived value helps a lot in the foundation of brand trust that take customer towards loyalty. Earlier researches affirms perceived value to be significant with customer satisfaction but our study investigates and discover the insignificant relationship between perceived value and customer satisfaction by regression analysis having weight $(\beta=.073)$ and $(\mathrm{p}>0.05)$. Younger respondents were focused mainly in this research and they were observed to the high perceived value with relative product if mainly sample consist of adults then results could be different for this relation.

This research indicates some advices for the companies to follow for the foundation of brand loyalty. Companies must have to focus on the promotion means like media and advertising etc. but have to represent the actual picture of the product and stop in avoiding of the statements on that they can't justify. Any company in the world If want to be successful, they should have to give numerous and affective details to their customer so that they buy their services and products. By this manner companies can get complete loyalty. Lastly, this paper recommended the ways of developing brand loyalty for the companies.

\section{Limitations and future research}

As like other projects researches, our study also has certain restricted boundaries that may possibly provide other promising paths for further exploration. In this research we study and investigated the effect of service quality, perceived quality, perceived value, brand trust and customer satisfaction on brand loyalty. This study was focused mainly to undergraduate and graduate students. Among these students loyalty towards Hewlett Packard brand products were examined or observed. From the found results brand trust and customer satisfaction has highest effect on brand loyalty. For additional explorations, the elements effective on the growth of trust and customer satisfaction are recommended to examine in future. Furthermore, consider the different product while investigating brand loyalty among customers because loyalty consequences may show discrepancy dependent on product variation. Likewise, youth 
outlooks towards loyalty may possibly vary from adults. For that reason, future researches are needed to examine the affective factors on loyalty in standings of altered consumer sets. Various respondents had complications to understand the items given in questionnaire because in Pakistan natural language is Urdu. To resolve this dispute, by building a questionnaire in native language for understanding of respondents, usage of substitute words or reshaping the item questions may be very beneficial for future research. For the detailed investigation of brand loyalty among customers added more items in the study. In addition, to understand the detailed concept of customer-brand relationship further processes of service quality, perceived value and perceived quality could be investigated for the enhanced conclusions. Regardless with the significance of this conception, according to (Chaudhuri and Holbrook, 2001) the dimensions of brand loyalty have not grown in promotion works. Thus the outcomes or upshots of this investigation would be used or treated with attentiveness and carefulness. The investigation would be strong and accurate by enhancing the size of sample composed of the respondents to be taken from other geographical zones.

\section{References}

(1)Amine, A. (1998) "Consumers' True Brand Loyalty: The Central Role of Commitment", Journal of Strategic Marketing, Vol.6, pp.305-319.

(2)Anderson, R.E., \&Srinivasan, S.S. (2003) "E-satisfaction and e-loyalty: A contingency framework", Psychology \&Marketing, Vol.20, No.2, pp.123-138.

(3)Agustin, Clara and Singh Jagdip (2005) "Curvilinear Effects of Consumer Loyalty Determinants in Relational Exchanges", Journal of Marketing Research, XIII

(4)Ballester-Delgado Elena and Aleman-Munuera Jose (2001) "Brand Trust In the Context of Consumer Loyalty", European Journal of Marketing, Vol.35, No.11/2, pp.1238-1258.

(5)Bloemer, J. M. M. and Kasper, H. D. P. (1995) "The Complex Relationship between Consumer Satisfaction and Brand Loyalty", Journal of Economic Psychology, Vol.16, pp.311-329.

(6)Brown, G. (1952) "Brand Loyalty: Fact or Fiction?", Advertising Age, Vol.23, pp.53-55.

(7)Bitner, Mary Jo (1990), "Evaluating Service Encounters; The Effects of Physical Surroundings and Employee Responses", Journal of Marketing, Vo.54, April 1990, p.69-82

(8)Bennett R, Härtel C, McColl-Kennedy JR (2005). Experience of a moderator of involvement and satisfaction on brand loyalty in a business-to-business setting 02-314R. Indus. Mar. Manage., 34: 97- 107.

(9)Bloemer, J.M. and Kasper, H.D.P. (1995), "The complex relationship between customer satisfaction and brand loyalty", Journal of Economic Psychology, Vol. 16 No. 2, pp. 311-29.

(10)Bloemer, J.M. and Ruyter, K. (1998), "On the relationship between store image, store satisfaction and store loyalty”, European Journal of Marketing, Vol. 32 Nos 5/6, pp. 499-513. 
(11)Bennett, R., Rundle-Thiele, S. (2005) 'The brand loyalty life cycle: Implications for marketers', Journal of Brand Management, vol.12, no.4

(12)ChaudhuriArjun,HolbrookB.Moris, (2001), "The Chain Of Effects From Brand Trust And Brand Affects To Brand Performance: The Role of Brand Loyalty", Journal of Marketing Vol.65, p.81-93

(13)Caceres Ruben ChumpitazandPaparoidamis Nicholas G., (2007), "Service Quality, Relationship Satisfaction, Trust, Commitment and Business-T-Business Loyalty", European Journal of Marketing Vol.41 No. 7/8, 2007 p.836-867

(14)Caceres, Ruben Chumpitaz and Paparoidamis, Nicholas G. (2007) "Service Quality, Relationship Satisfaction, Trust, Commitment And Business-T-Business Loyalty", European Journal of Marketing Vol.41 No.7/8, pp.836-867

(15)Cemal, Z, Azize S, Hakan K., Mehtap Ö. (2011) "The Effects of Brand Communication and Service Quality in Building Brand Loyalty Through Brand Trust; The Empirical Research On Global Brands ", Procedia Social and Behavioral Sciences, Vol.24, pp. 1218-1231.

(16)Chang, S.-C. (2005) "The Dimensions and Measurement Items of Perceived Value on Tourism Services", Service Industry Management Review, Vol.1, No.1, pp.105-28.

(17)Chaudhuri, A. \& Holbrook, M. B. (2001) "The chain of effects from brand trust and brand affect to brand performance: The role of brand loyalty", Journal of Marketing, Vol.65, No.2, pp.81-93.

(18)Caruana A (2002). Service loyalty: the effects of service quality and the mediating role of customer satisfaction. Eur. J. Mar., 36(7/8): 811-828.

(19)Chaudhuri A, Holbrook MB (2001). The chain of effects from brand trust and brand affect to brand performance: the role of brand loyalty. J. Mar., 65(2): 81-93.

(20)Chaudhuri, A., \& Holbrook, M.B. (2001). The chain of effects from brand trust and brand affect to brand performance: The role of brand loyalty Journal of Marketing, 65(2), 81-93.

(21)Cronin, J.J., Brady, M.K.., \&Hult, G.T.M. (2000). Assessing the Effects of Quality, Value and Customer Satisfaction on Consumer Behavioural Intentions in Service Environment, Journal of Retailing, 76 (2), 193

(22)Chaudhuri, A. and Holbrook, M.B. (2001), "The chain of effects from brand trust and brand affect to brand performance: the role of brand loyalty", Journal of Marketing, Vol. 65 No. 2, pp. 81-93.

(23)Dick, Alan S. and KunalBasu (1994), "Customer Loyalty: Toward an Integrated Conceptual Framework," Journal of the Academy of Marketing Science, 22 (Spring), 99-113.

(24)Day, G.S. (1969), “A two-dimensional concept of brand loyalty”, Journal of Marketing Research, Vol. 9, pp. 29-36. 
(25)Darsono, L.I, \&Junaedi, C.M. (2006), An examination of perceived quality, satisfaction and loyaltyrelationship GadjahMada International Journal of Business, 8 (3), 323-42.

(26)Fournier Susan \& Mick Glen David, (1999), Rediscoandring Satisfaction, Journal of Marketing Vol.63 (October 1999), 5-23 CemalZehir et al. / Procedia Social and Behavioral Sciences 24 (2011) 1218-1231 1229

(27)Gustafsson Anders, Johnson Michael D.,RoosInger, (2005), The Effects Of Customer Satisfaction, Relationship Commitment Dimensions, And Triggers On Customer Retention, Journal Of Marketing 69,210-218

(28)Garbarino\& Johnson S.Mark, 1999, the Different Roles of Satisfaction, Trust, and Commitment in Customer Relationships, Journal of Marketing Vol.63 (April 1999), 70-87

(29) Grace, Debra and O'Cass, Aron (2005), "Examining the effects of service brand communications on brand evaluation", The Journal of Product and Brand Management. Santa Barbara: 2005. Vol. 14, Iss. 2/3; pg. 106, 11 pgs

(30)González MEA, Comesaña LR, Brea JAF (2007).Assessing tourist behavioural intentions through perceived service quality and customer satisfaction. J. Bus. Res., 60: 153-160.

(31)Gotlieb JB, Grewal D, Brown SW (1994). Consumer satisfaction and perceived quality: complementary or divergent constructs? J. App Psychol., 79(6): 875-885.

(32)Giese, J.L. and Cote, J.A. (2000), "Defining customer satisfaction", Academy of Marketing Science Review, Vol. 20 No. 1, pp. 1-27.Gommans, M., Krishnan, K.S. and Scheffold, K.B. (2001), "From brand loyalty to e-loyalty: a conceptual framework", Journal of Economic and Social Research, Vol. 3 No. 1, pp. 43-58.

(33)Getty, J. M., \& Thompson, K. N., (1994).The relationship between quality, satisfaction, and recommending behavior in lodging decision. Journal of Hospitality and Leisure Marketing, 2(3), 3-22.

(34)Gronroos, C., (1988). Service quality: The six criteria of good perceived service quality. Review of Business, 9(3), 10-13.

(35)Hsteh, Yi-ChingandHiangShu-Ting, (2004), A Study of The Impacts of Service Quality On Relationship Quality In Search Experince Credence Sevices, Total Quality Management, Vol.15, No.1, 43-48

(36)Hennig-ThurauThorstenand Klee Alexander, (1997), The Impact of Customer Satisfaction and Relationship Quality On Customer Retention: A Critical Reassessment and Model Deandlopment, Psyhology\&MarketingVol.14(8):737-764 (December 1997)

(37) Ha Youl-Hong, Perks Helen, (2005), "Effects of Consumer Perceptions of Brand Experience On The Web: Brand Familiarity, Satisfaction and Brand Trust", Journal of Consumer Behaviour Vol. 4,6, 438-42

(38) Hess Jeff, Story John, (2005), “Trust-Based Commitment: Multidimensional Consumer-Brand Relationships", Journal of Consumer Marketing 22/6 313-322 
(39)Ha H, Janda S, Park S (2009). Role of satisfaction in an integrative model of brand loyalty: evidence from China and South Korea. Int. Mar. Rev., 26(2): 198-220.

(40)Hsteh, Yi-ChingandHiangShu-Ting (2004), "A Study of The Impacts of Service Quality On Relationship Quality In Search Experience Credence Services, Total Quality Management, Vol.15, No.1, pp.43-48.

(41) Jacoby, Jacob, Chestnut, Robet W. and Fisher, William, A., (1978), "A Behavioral Process Approach to Information Acquisition in Nondurable Purchasing", Journal of Marketing Research, Vol.XV, s.532-544

(42) Jacoby, Jacob and D.B. Kyner (1973), "Brand Loyalty Versus Repeat Purchasing," Journal of Marketing Research, 10 (February), 1-9.

(43)Jacoby, J. and Chestnut, R.W. (1978), Brand Loyalty: Measurement and Management, Wiley, New York, NY.

(44)Jacoby, J. and Kyner, D.B. (1973), "Brand loyalty versus repeat purchasing”, Journal of Marketing Research, Vol. 10, pp. 1-9.

(45)Jacoby, W and. Chestnut. R. (1978) Brand Loyalty: measurement and management, John Wiley and Sons, New York.

(46)Knox Simon, Walker David, (2001),'Measuring and Managing Brand Loyalty", Journal of Strategic Marketing 9 111- 128

(47) Morgan M.Robert\& Hunt D. Shelby, (1994), “The Commitment-Trust Theory of Relationships Marketing”, Journal of Marketing, Vol.58 (July 1994), 20-38

(48) Moorman, Christine, Deshpande, Rohit and Zaltman, Gerald, (1993), "Factors Affecting Trust In Market Research Relationships", Journal of Marketing, Vol.57, S.81-101

(49)Moorman, C., Deshapande R., \& G. Zaltman (1992), Factors affecting trust in market research relationships, Journal of Marketing, 57, 1: 81-101

(50)Moorthy, S. and Zhao, H. (2000), “Advertising spending and perceived quality”, Marketing Letters, Vol. 11 No. 3, pp. 221-33.

(51)Oliver, R.L. (1997), Satisfaction: A Behavioral Perspective on the Consumer, McGraw-Hill, New York, NY.

(52)Olsen SO (2002).Comparative evaluation and the relationship between quality, satisfaction, and repurchase loyalty. J. Acad. Mar. Sci., 30(3): 240-249.

(53)O'Mally, L. (1998) "Can Loyalty Schemes Really Build Loyalty?", Marketing Intelligence and Planning, Vol.16, No.1, p.49.

(54)Olsen, S.O. (2002), "Comparative evaluation and the relationship between quality, satisfaction, and repurchase loyalty", Journal of the Academy of Marketing Science, Vol. 30 No. 3, pp. 240-9. 
(55)Parasuraman A., Zeithaml A. Valarie \& Berry L.Leonard, (1985), "A Conceptual Model of Service Quality and Its Implications for Future Research", Journal of Marketing Vol.49 (Fall1985) 41-50

(56)Parasuraman, A., Zeithaml, Valarie Al., and Berry Leonard L., (1988), "Servqual; A Multiple-Item Scale For Measuring Consumer Perceptions of Service Quality", Journal of Retailing, Vol.64, p.12-40

(57)Parasuraman, A. and Grewal, D. (2000), "The impact of technology on the quality-value-loyalty chain: a research Agenda", Journal of the Academy of Marketing Science, Vol. 28 No. 1, pp. 168-74.

(58)Parasuraman, A. and Grewal, D. (2000), "The impact of technology on the quality-value-loyalty chain: a research Agenda", Journal of the Academy of Marketing Science, Vol. 28 No. 1, pp. 168-74.

(59)Patterson, P.G. \&Spreng, R.A. (1997) "Modeling the relationship between perceived value, satisfaction and repurchase intentions in a business-business, services", Industry Management, Vol.8, No.5.

(60)Petrick, J. F. (2002) "Development of a Multi-Dimensional Scale for Measuring the Perceived Value of a Service", Journal of Leisure Research, Vol.34, No.2, pp.119-34.

(61)Petrick, J. F. (2004b) "First Timers' and Repeaters' Perceived Value", Journal of Travel Research, Vol.43, No.1, pp.29-38.

(62) Rizwan, M., Akbar, I., Muqtadir, A., Shafique, U., Zia, H., Naseer, W. and Amin, S. A. (2013) Impact of Brand Switching, Brand Credibility, Customer Satisfaction and Service Quality on Brand Loyalty, IOSR Journal of Business and Management, Vol. 1 (special issue), $12-20$

Rizwan, M., Usman, A., Hussain, T., Shafiq, A., Rauf, S. \& Ayaz, Q., (2013) The Impact of the Perceived Quality, Customer Satisfaction, Brand Trust and Contextual Factors on Brand Loyalty, International Journal of Research in Commerce and Management, 4(3), 83-89

Ribbink, Diana, C.R.Allard Van Riel, LiljanderAndronica and Strewkens, Sandra, (2004), "Comfort Your Online Customer; Quality, Trust and Loyalty On The Internet, Managing Service Quality', Vol 14, p.446-456

(63)Sheth, Jagdish N, (1968), “A Factor Analytical Model of Brand Loyalty”, Journal of Marketing Research (JMR), Nov68, Vol. 5 Issue 4, p395-404, 10p

(64)Sheth, Jagdish N.; Park, C. Whan , (1974), "A Theory of Multidimensional Brand Loyalty.”, Advances in Consumer Research, 1974, Vol. 1 Issue 1, p449-459, 11p

(65)Selnes Fred, (1993), "An Examination of the Effect of Product Performance on Brand Reputation Satisfaction and Loyalty", European Journal of Marketing Vol.27 No.9 Pp.19-35

(66)Syzmanski, D. M., \&Henard, D. H. (2001), Customer Satisfaction: A Meta-Analysis of the Empirical Evidence, Journal of the Academy of Marketing Science, 29 (1), 16-35. 
(67)Saleh, F., \& Ryan, C. (1991).Analyzing service quality in the hospitality industry using the SERVQUAL model. The Service Industries Journal, 11(3), 324-343.

(68)Suhartanto, D. (2011), “An Examination of Brand Loyalty in the Indonesian Hotel Industry”, Lincoln University Digital Thesis, Christchurch New Zealand

(69)Terblanche, N.S. and Boshoff, C., (2001), "Measuring Customer Satisfaction With The Controllable Elements of The In- Store Shopping Experience", S.Afr.Bus.Manage., 32, p.8-18

(70)TePeci, M. (1999) "Increasing brand loyalty in the hospitality industry", International Journal of Contemporary Hospitality Management, Vol.11, No.5, pp.223-229.

(71)Tellis, G.J. (1988), "Advertising exposure, loyalty, and brand purchase: a two-stage model of choice”, Journal of Marketing Research, Vol. 25 No. 2, pp. 134-44.

(72)Wheatley, J.J. and Chiu, J.S. (1977), "The effects of price, store image, and product and respondent characteristics on perceptions of quality", Journal of Marketing Research, Vol. 14, May, pp. 181-6.

(73)Wilkins, H., Merrilees, B., \& Herington, C. (2007).Towards an understanding of total service quality in hotels. Hospitality Management, 26(4), 840-853.

(74) Yi Youjae and Suna La, (2004), "What Influences the Relationship Between Customer Satisfaction and Repurchase Intention? Investigating the Effects of Adjusted Expectations and Customer Loyalty", Psychology \& Marketing Vol. 21(5): p.351- 373 (May 2004).

(75) Yang Zhilin, Peterson T. Robin, (2004), “Customer Perceived Value, Satisfaction, and Loyalty: The Role of Switching Costs", Psychology\& Marketing Vol.21 (10): p. 799-822 (October 2004)

(76)Zeithaml, Valarie A.; Berry, Leonard L. and Parasuraman A., (1996), "The Behavioral Consequences of Service Quality”, Journal of Marketing, Vol.60, p.31-46.

(77)Zeithaml, V.A. (1988), perceptions of price, quality, and value: A meansend model and synthesis of evidence, Journal of Marketing, 52 (July), 2-22

(79)Zeithaml, V. A., Berry, L. L. \&Parasuraman, A. (1996) "The behavioral consequences of service quality. Journal of Marketing, Vol.60, No.4, pp.31-46.

(80)Zeithaml, V.A. (1988) "Consumer perceptions of price, quality, and value: A means-end model and synthesis of evidence", Journal of Marketing, Vol.52, No.3, pp.2-22.

(81)Zeithaml, V., Berry, L.L. and Parasuraman, A. (1996), “The behavioral consequences of service quality", Journal of Marketing, Vol. 60, April, pp. 31-46.

(82)Zeithaml, V.A. (1988). Consumer perceptions of price, quality, and value: a means-end model and synthesis of evidence. Journal of Marketing, 52, 2-22, July. 